\title{
The reinforcement of craft and entrepreneurship education in senior high schools
}

\author{
Sugiono, Trisno Martono, Dewi Kusuma Wardani
}

Universitas Sebelas Maret, Indonesia

\begin{tabular}{l} 
Article Info \\
\hline Article history: \\
Received May 07, 2018 \\
Revised Des 31, 2018 \\
Accepted Jan 20, 2019 \\
\hline
\end{tabular}

Keywords:

Craft and entrepreneurship education

\begin{abstract}
This research aimed to find out the constraints occurring in the implementation of craft and entrepreneurship education. This research employed qualitative research method. The research was taken place in three schools in DKI Jakarta as the beneficiaries of entrepreneurship program grant from the government. Data was collected through interview and observation. The result of research showed the less optimum implementation of craft and entrepreneurship education. The constraints the teacher encountered in the implementation of Craft and Entrepreneurship subject were: teacher having no background of Entrepreneurship Education, No Subject Teacher Discussion (MGMP) group available and no supporting activity for Craft and Entrepreneurship subject. Therefore, this research recommended the reinforcement of entrepreneurship education learning through establishing MGMP team, teacher training, and sustainable integration of entrepreneurship subject and program.
\end{abstract}

Copyright $@ 2019$ Institute of Advanced Engineering and Science. All rights reserved.

Corresponding Author:

Sugiono,

Master of Economics Education,

Sebelas Maret University,

Ir. Sutami Street No.36A, Jebres, Surakarta, Central Java 57126, Indonesia.

Email: sugi.sugiono.91@ gmail.com

\section{INTRODUCTION}

Time change requires education realm to make innovation in the attempt of contributing to preparing human resource to have competiveness. National education system has a variety of duties and responsibilities to give solution to challenge and opportunities in global era. Thus, it is expected that Indonesia can win the competition in the future. The policy released should be implemented intensively by government as the corrective attempt, regarding system, organization pattern, facility, and the improvement of teacher quality and other components related to education realm. The policy made is intended to improve the quality of education, to answer the time demand and to promote the development of knowledge and technology.

Education at Senior High School level in Indonesia has a challenge. The number of opened unemployment by education level is the highest one during 2011-2015 and it increases over times at secondary school level. In 2011, the number of Senior High School graduates contributes unemployment number of 2.376.254, and in 2012, this number decreases to 1.867.755. However, in 2013-2015 it increases successively: $1.925 .660 ; 1.962 .786$; and 2.280.029 [1].

McKinsey Global Institute [2] stated that demographic transition will occur in Indonesia that will open the demographic bonus opportunity during 2030. Indonesia is predicted to have a larger number of populations with productive age identical with the secondary school student age; it will impact on the higher opportunity and potency of improving productivity, thereby improving its population's wellbeing.

Considering the ideal expectation, Human Resource Development in productive age through Senior High School education in Indonesia becomes a very important target. Senior High School education is 
expected to result in a high-quality graduate that can adapt to the change and are competitive at global scale. It is because Indonesia as the state with large potency has an opportunity of being the one with developed economy. There should be a policy that can encourage the creation of young entrepreneurship and empower the entrepreneurship as the attempt of supporting national development. Demographic bonus should also be followed with the even distribution of education and the improvement of human resource quality, so that demographic bonus becomes a potency that can be maximized for the state advance.

Considering the Republic of Indonesia Education and Culture Minister's Regulation Number 81A of 2013 about Curriculum Implementation [3], learning should support the students to develop entrepreneurship spirit and life competency skill of students. This fact occurring requires the Senior High School Education to equip its graduates with a science to create job opportunity. The intended science is entrepreneurship science. The reinforcement of entrepreneurship education is expected to change the mind set of Senior High School graduates no longer to be job seeking-oriented but to have vision to create job opportunity. That is why the smart entrepreneurship should be quipped with knowledge, insight, skill, mindset, strategy and tactic.

Kao defines entrepreneurship as entrepreneur's attitude and behavior; entrepreneur is an innovative, anticipative, initiative, risk-taking, and profit-oriented one [4]. Zimmerer defines entrepreneurship as the product of a discipline, a systematic process in applying creativity and innovation in the attempt of meeting the market need and opportunity [5]. Meredith [6] states that the characteristics of those having entrepreneurial spirit are: self-confident, task-and outcome-oriented, taking risk bravely, having leadership spirit, future-oriented, and original. From definitions above, the entrepreneurial values have been mentioned as well. The inculcation of entrepreneurial values can be done through education channel. The entrepreneurship-based education is the one applying principles and methodology toward the internalization of values into the students through a curriculum integrated into the development occurring in both school and society environment and the use of learning model and strategy relevant to the objective of learning [7].

Indonesian Government, through Presidential Instruction Number 4 of 1995 about National Movement of Socializing and Cultivating Entrepreneurship mandates all Indonesian people to develop entrepreneurship programs. Mulyani [6] in her study states that the government's attempt of socializing entrepreneurship has not exerted a significant effect yet. The success of entrepreneurship education program can be seen from the achievement of students, teacher and headmaster. Students have high entrepreneurship character, attitude and behavior. Class environment can develop student habit and behavior consistent with entrepreneurship values internalized. School life environment serves as the learning environment with entrepreneurship nuance supporting entrepreneurship activity. In his study, Winarno [7] found that the entrepreneurship values the students have are relatively less optimal, so that it indicates that the entrepreneurship attitude of students has not been established well. Maryati [8] considers the need for a policy that can support the birth of young entrepreneur and to empower it to support national development. There should be synergy of all stakeholders to contribute actively to socializing entrepreneurship, thereby having implication to the creation of entrepreneurship attitude that will support national education.

The development of entrepreneurship talent is important to maintain the competitive advantage in global economic competition based on innovation. The role of high-quality education in improving the students' entrepreneurship potency is important and can be the alternative to career choice. An entrepreneurship-based education is the one applying principles and methodology to internalize the values into the students through a curriculum integrated into the development occurring in both society and global environments and the use of learning strategy relevant to the learning objective. Entrepreneurship education becomes an important capital (asset) for the students. An outcome of entrepreneurship education is that the students can resolve conflict and be more responsible. Education institution is responsible for improve the graduates' life competency as the capital to deal with any changes occurring in the society.

Teacher is an important factor in spurring the quality of education, so that the improvement of teacher competency is a must. Teacher becomes an actor in learning process in which teacher acts as learning facilitator, motivator, activator, and inspirer. There are three main preconditions of education development in the attempt of improving human resource quality: building infrastructure, high-quality book, and professional teacher and educational staff [9]. The improvement of professional teacher is an attempt of helping the less professional teacher to have professional ability.

The improvement of teacher's professionalism is conducted merely to realize the improvement of education quality and the achievement of education objective. Teacher becomes the key actor to education advance. Teacher becomes a starting point in transforming values. Teacher, as educator, is responsible for sending down values and norms to the students; in the presence of value transformation, value conservation process will occur because education process is an attempt of creating new values.

From the result of research, the following problems are found: Teacher of Craft and Entrepreneurship subject does not have Entrepreneurship education background; there is no Subject Teacher Discussion (MGMP) group so that for Craft and Entrepreneurship subject, every teacher should 
make elaboration according to their ability, and there is no supporting activity for the Craft and Entrepreneurship subject.

The implementation of Craft and Entrepreneurship education in the attempt of improving Senior High School graduates in order to have high competitiveness should involve all of stakeholders including government, school component, and community component. One of actors important to school component is teacher. Teacher plays an important role in the attempt of transforming entrepreneurship values to the students so that the students can define and conceive entrepreneurship values that will have implication to the creation of student character with entrepreneurship character. The Craft and Entrepreneurship education is so important at Senior High School that there should be reinforcement in craft and entrepreneurship education subject. The reinforcement of craft and entrepreneurship education subject aims to achieve the objective of craft and entrepreneurship education.

\section{RESEARCH METHOD}

This research employs a qualitative method, according to Richie and Lewis [10], defined as the attempt of presenting social realm and its perspective in the world, from concept, behavior, perception and problem of human beings studied. This qualitative research employed phenomenological approach. Creswell [11] mentions that phenomenological study describes a number of individuals' general interpretation on their life experience related to concept or phenomena. Social situation becoming the object of research was schools existing in DKI Jakarta as the beneficiaries of program entrepreneurship grant from government. The sampling technique used is purposive sampling. Glaser \& Strauss [12] states that the use of purposive sampling technique is not intended to be representative or typical but to maximize the scope of information found. The collection of data using interviews, observation and study of the document. Moleong [13] states that data source and type involved are words and action, written source, photograph and statistic data.

\section{RESULTS AND ANALYSIS}

\subsection{Education Background of Craft and Entrepreneurship Teacher}

The education background of teacher becomes main constraint in implementing craft and entrepreneurship education. It is in line with the result of interview with Vice-Headmaster of SMA N 66 Jakarta stating that: "Our biggest constraint is that we do not have pure entrepreneurship teacher. It is the biggest constraint, while other constraints can be solved, for example, we can deal with the processingrelated learning by discussing it with the division. The presence of entrepreneurship officer will make it easier. The school lacks of entrepreneurship teacher, so that entrepreneurship subject is assumed by the teachers with no entrepreneurship background. To deal with such the problem, every teacher holds discussion before delivering material to the students".

The result of interview with the craft and entrepreneurship subject shows that a teacher said "I have Japanese language education background but I am asked for teaching Entrepreneurship. I think it is very far away from my education background; then I have prior mindset that entrepreneurship is only limited to trading and I do not have trading ability and experience. The learning conducted is consistent with teacher's ability so that I deliver material of textile craft. It is confirmed by the second teacher saying that "the biggest problem is my chemistry education background, so that any time we come to the new material or chapter, I should think hard related to the material I should deliver to the students. To deal with it, I search for material via internet and sometimes the material in internet is different from that in textbook".

The students respond to the craft and entrepreneurship subject as follows: "Yeah, it is less clear; then I think that the teacher understands poorly what the entrepreneur is, so we should explore ourselves to get the meaning of entrepreneur; and the class makes us bored because the learning process delivers theory only and learning process is developed inadequately.

Overall, the result of interview shows that the education background of entrepreneurship teacher at school is varying from physics, chemistry, mathematics, to Guiding and Counseling teachers. There is no entrepreneurship subject teacher with education background so that its learning development is adjusted with the ability of corresponding teacher. The effect of varying education background is that the students consider that the teachers cannot develop craft and entrepreneurship subject.

Suryadi [14]mentions that the professional teacher will result in learning program that can motivate the students to learn and can impact greatly on the students' achievement. Law Number 14 of 2005 about Teacher and Lecturer[15], in article 1 clause 1, mentions that teacher is a professional educator in charge of educating, teaching, guiding, directing, training, assessing, and evaluating the students in early age child education of formal education, primary education and secondary education. In article 1 clause 2 , it is mentioned that the teacher serves as a professional personnel in primary, secondary and early age child 
education in formal education channel hired corresponding to the legislations. Regarding teacher competency, as included in Article 10, teacher should have four main competencies: pedagogic competency, personality competency, social competency, and professional competency acquired through professional education. Teacher plays a very vital role because he/she contributes to determining the students' successful learning, particularly in teaching-learning process. Teacher should prepare the procedure of learning process. The procedure includes planning, implementation, and assessment. As an educator, teacher serves as caretaker, forwarder, and translator of value systems becoming the source of habit norm prevailing in the society [16].

The improvement of education, particularly teacher competency, should be done continuously. Mulyani [7] mentions that the quality of process can be achieved when the learning process runs effectively and the students can conceive and interpret the learning process. The quality of product can be achieved when the students have ability of mastering the learning task corresponding to its need in life and work realm's demand. The improvement of teacher competency is important to ensure the successful learning process that will have implication to good learning product or outcome for the students. It is refers to the Republic of Indonesia Education and Culture Minister's Regulation Number 81A of 2013 about Curriculum Implementation [3] mentioning that the learning activity should support the students' growth and development in order to have entrepreneurship spirit and to have life competency. Thus, the students have good capital to continue to the next education level and/or to enter into work realm.

Considering the main problem in which the Craft and Entrepreneurship teacher does not have craft and entrepreneurship education background, Mulyasa [9] mentions that this education background should correlate positively to education quality, along with other factors affecting it; thereby it is necessary to improve the teacher ability. The attempts that can be taken to improve teachers' competency are: to hold training and to establish teacher network.

The development of education advance should be followed with the improvement of teachers' ability and skill. Knowledge, skill and attitude of teacher highly determine the learning process in education class and process at school. The improvement of teacher's knowledge, skill and attitude can be done through training channel. Sherman, Bohlander, and Churden [17] mention that training is the process utilized by organization to change the workers' behavior, contributing to overall mission, and personal and professional development of individuals involved. Training can improve ability and skill. The improvement of teacher's skill can have implication to support the teacher to develop competency, to encourage to solve the problem encountered and to help the teacher anticipate need and problem, and to formulate policy and action plan as suggested by Kydd [17].

Therefore, from the elaboration above, training should be held for craft and entrepreneurship teacher as the solution to the school in the attempt of dealing with varying education background of teacher. Training becomes the school institution or related institution's attempt of preparing professional teacher in entrepreneurship field. Training can be another factor in the attempt of reinforcing the craft and entrepreneurship education. This entrepreneurship training is intended to give the teachers the good understanding and perception on the subject they assume. Training can also improve teacher ability and/or skill, thereby having implication to the improvement of teacher competency.

The attempt that should be taken to improve teacher competency is to improve the network of subject teacher. Referring to the problem encountered, that is, no Subject Teacher Discussion (MGMP) available, such the team should be established. MGMP aims to improve teacher quality and professionalism in their own group [18]. The activity deriving from one of this study area clumps is conducted to discuss the problems related to the study field [19].

MGMP (Subject Teacher Discussion) is a forum/medium of subject teacher's professional activity in SMP/MTs (Junior High School/Islamic Junior High School), SMPLB/MTsLB (Junior High School/Islamic Junior High School for students with special needs), SMA/MA (Senior High School/Islamic Senior High School), SMK/MAK (Vocational Middle School/Islamic Vocational Middle School), SMALB/MALB (Senior High School/Islamic Senior High School for students with special needs) existing in one area/regency/city/sub district/studio/ school cluster) [20]. Corresponding to its objective, MGMP is a medium for teacher to expand insight, share experience, empower the member of group, improve education process quality, and improve teacher competency through activity at MGMP level. The establishment of MGMP team for craft and entrepreneurship subject teacher is important, recalling that the main problem of craft and entrepreneurship education implementation is teacher with no craft and entrepreneurship education background. The establishment of MGMP team becomes the solution to improve teacher ability referring to the objective of KKG (Teacher Work Group)/MGMP as included into the standard development of KKG/MGMP. Thus, the establishment of MGMP plays an important role in supporting activity and development of teacher professionalism. 
The successful implementation of craft and entrepreneurship education can be seen from teacher's understanding on entrepreneurship education because the teacher's high understanding on entrepreneurship will facilitate the teacher in implementing the entrepreneurship program [21]. In addition to have understanding on entrepreneurship, the teacher should be integrated into entrepreneurship [22]. Teacher plays an important role in the successful implementation of craft and entrepreneurship education, so that teacher should improve his/her competency through training.

\subsection{Integration of Subject and Sustainable Program}

The implementation of craft and entrepreneurship education needs a synergy of all components existing in school environment in order that the internalization of craft and entrepreneurship education values can run well. Through this integration, the students are expected to obtain awareness of the importance of entrepreneurship values in daily life, through learning process both inside and outside classroom [23].

Entrepreneurship values are integrated into learning sets (syllabus and learning implementation plan/RPP). Independency, creativity, risk taking, leadership, action-orientation and work hard are main values of entrepreneurship integrated into all subjects. The learning implementation plan is the plan describing learning procedure and organization to achieve a basic competency specified in standard content and elaborated in syllabus [24]. The components of RPP are at least consisted of: learning objective, material, method, source, and outcome evaluation. This implementation plan becomes a guideline for teacher in teaching-learning process.

Mulyasa [25] mentions four advantages of Learning Implementation Plan: firstly, explaining information related to the achievement of student competency, and preconditions needed by the students to attend the learning at school. Secondly, RPP improves the efficiency of implementation process. Thirdly, it implements the sustainable development process. Fourthly, it can be used to be an attractive scientific work product as the proposed material of position/grade promotion for an educator, so that a learning plan should be designed corresponding to standard content and basic competency at different grade level.

The craft and entrepreneurship education values can be integrated into learning set and can be implemented by every subject teacher through connecting the material to craft and entrepreneurship. The result of interview shows "every subject has correlation to entrepreneurship, for example, biology subject can be connected to cultivation material that can yield money".

It is confirmed with the result of interview with teacher mentioning that "Everything works. So the curriculum integrates into craft and entrepreneurship teacher, and it is embodied into all teachers. It means that all teachers have responsibility". The integration of craft and entrepreneurship subject becomes important in the attempt of internalizing entrepreneurship values to students, those values can also be the foundation for students in the attempt of creating character.

The integration can also be done through extracurricular activity at school. One objective of extracurricular activity is to develop the students' competency as the complement of teaching-learning activity in the classroom. Extracurricular activity impacts positively on giving the students an understanding on entrepreneurship. For example, a student of SMA N 66 Jakarta suggests that "I am originally not interested in entrepreneur. This prior thinking is related to my assumption about entrepreneurship that wastes time only. Having attended Student Company extracurricular activity, I feel that entrepreneurship is important and can equip me with the skill after I am graduated from Senior High School".

Then teacher of craft and entrepreneurship subject informs that "there is a very prominent difference between students attending entrepreneurship extracurricular activity and those not; the students attending are more active and understand the entrepreneurship better because they are built by an institution operating in entrepreneurship field".

In addition to through integration, the Craft and Entrepreneurship Education subject in Senior High School is the program of identifying entrepreneurship concept, developing entrepreneurship value, practicing business development, obtaining practical experience with entrepreneurship, growing an interest in being entrepreneur, and developing entrepreneurship potency [26]. Organizing entrepreneurship program should be done systematically through curriculum and learning conducted sustainably. The presence of entrepreneurship program at Senior High School level gives the students the opportunity of developing their potency in entrepreneurship field in addition to going beyond the learning process in the classroom.

Entrepreneurship program can also give empirical experience to the students related to entrepreneurship so that the students can understand the meaningfulness of entrepreneurship. The meaningful education is organized with orientation to empowerment, and to the creation of noble character, disposition, personality, or superior character, and life competency [21]. This entrepreneurship program should also be developed corresponding to the school's potency, so that the program implemented can run effectively and achieve the target appropriately. 


\section{CONCLUSION}

The reinforcement of craft and entrepreneurship education in Senior High School education unit is the attempt of producing Senior High School graduates with entrepreneurship spirit and life competency. Craft and entrepreneurship education is expected to be the solution to Indonesia in order to prepare the competitive human resource in global competition and to utilize the opportunity of demographic opportunity. The implementation of craft and entrepreneurship education still find some constraints: No Subject Teacher Discussion (MGMP) group is available and there is no supporting activity for Craft and Entrepreneurship subject.

This research gives some recommendations to deal with those problems. Firstly, MGMP team should be established to be the teachers' medium of expanding their insight and to improve teacher professionalism, secondly, training should be held in the attempt of improving teachers' understanding and perception on entrepreneurship, thereby having implication to the successful learning implementation. Thirdly, subject should be integrated, by including entrepreneurship values into the learning set. Fourthly, the sustainable entrepreneurship program can give the students the empirical and practical experience with entrepreneurship. These attempts can be the solution to the reinforcement of entrepreneurship education in internalizing entrepreneurship values.

\section{ACKNOWLEDGEMENTS} data source.

The writers give thanks to SMA N 66 Jakarta, SMA N 61 Jakarta and SMA N 79 Jakarta for as the

\section{REFERENCES}

[1] Central Bureau of Statistics, Open unemployment according to the highest education completed (in Bahasa), 2016.

[2] McKinsey Global Institute. The archipelago economy: Unleashing Indonesia's potential. Paperback, Sep 18, 2012.

[3] Minister of Education and Culture Regulation Number 81A of 2013 about Curriculum Implementation.

[4] Suherman M., Entrepreneurship learning design (in Bahasa), Bandung: Alfabeta, 2008.

[5] Suryana., Entrepreneurship: Tips and processes for success (in Bahasa), Jakarta: Salemba Empat, 2013.

[6] Winarno A., "Development of learning models internalization of entrepreneurship values in schools that prevent genuity in Malang City," Jurnal Ekonomi Bisnis, vol. 14, no. 2, 2009.

[7] Mulyani E., "Entrepreneurship education model in primary and secondary education," Jurnal Ekonomi dan Pendidikan.vol. 8, no. 1, 2011.

[8] Maryati S., "Dynamics of educated unemployment: Challenges toward demographic bonuses in Indonesia (in Bahasa)," Journal of Economic and Economic Education, vol.3, no. 2, pp. 124-136, 2015.

[9] Mulyasa, Become a professional teacher (in Bahasa), Bandung: PT Remaja Rosdakarya, 2013.

[10] Ritchie, J. and Lewis J., Qualitative research practice. A guide for social secience students and researchers. London: SAGE Publications, 2003.

[11] Creswell J.W., Qualitative research \& research design choosing among five approaches (in Bahasa), Third Edition Approaches. In Translate Ahmad Lintang Lazuardi. Yogyakarta: Student Library, 2015.

[12] Kalof L.,.Dan A. and Dietz T., Essentials of social research, New York: McGraw-Hill Education, 2008.

[13] Moleong L.J., Qualitative research methodology (in Bahasa). Revised Edition. Bandung: Rosda, 2016.

[14] Suryadi A., Indonesian education towards 2025 (in Bahasa). Bandung: PT Remaja Rosdakarya, 2014.

[15] Law of the Republic of Indonesia Number 14 of 2005 About Teachers and Lecturers.

[16] Natsir N.F., " Improving teacher quality in the islamic education perspective (in Bahasa)," Educationist. vol. 1, no. 1, 2007.

[17] Musfah J., Increasing teacher competency through training and learning theory and practical resources (in Bahasa). Jakarta: Kencana, 2011

[18] Mulyasa, Teacher compliance standards and certification (in Bahasa), Bandung: PT Remaja Rosdakarya, 2012.

[19] Suyanto and Jihad A., Become a professional teacher (in Bahasa), Jakarta: Erlangga, 2013.

[20] Directorate of Educator Profession, 2008.

[21] Sugiharsono Lestari B. and Sagoro E.M., "Implementation of entrepreneurship education in high schools and vocational schools welcomes the implementation of the 2013 curriculum," Educational Journal, vol 44, no. 1, pp. 64-72, 2014.

[22] Wibowo A., Entrepreneurship education, concepts and strategies (in Bahasa), Yogyakarta: Pustaka Pelajar, 2011.

[23] Republic of Indonesia Ministry of Education and Culture, Entrepreneurship Education Development. Training Materials Strengthening Learning Methodologies Based on Cultural Values to Form National Competitiveness and Character (in Bahasa), Jakarta: Badan Penelitian dan Pengembangan Pusat Kurikulum, 2010.

[24] Isdisusilo, Complete guideline for syllabus and RPP (in Bahasa), 2012.

[25] Mulyasa, Implementation of KTSP, Independence of teachers and principals (in Bahasa), Jakarta: Bumi Aksara, 2008.

[26] Directorate of High School Development, Directorate General of Primary and Secondary Education, Concept and Entrepreneurship Implementation Strategy in Senior High School, 2016. 